\author{
Asian Journal of \\ Medical and Biological Research \\ ISSN 2411-4472 (Print) 2412-5571 (Online) \\ www.ebupress.com/journal/ajmbr
}

\title{
Article \\ Moringa leaf meal as natural feed additives on the growth performance and meat quality of commercial broiler chicken
}

\author{
Md. Sazedul Karim Sarker ${ }^{1}$, Md. Masud Rana ${ }^{1}$, Halima Khatun ${ }^{1}$, Shakila Faruque ${ }^{1}$, Nathu Ram Sarker ${ }^{1}$, \\ Farhana Sharmin ${ }^{2}$ and Md. Nazrul Islam ${ }^{3}$ \\ ${ }^{1}$ Poultry Production Research Division, Bangladesh Livestock Research Institute, Savar, Dhaka, Bangladesh \\ ${ }^{2}$ Graduate School of Marine Science and Technology, Tokyo University of Marine Science and Technology, \\ Konan 4-5-7, Minato, Tokyo108-8477, Japan \\ ${ }^{3}$ Ex-Director General, Bangladesh Livestock Research Institute, Savar, Dhaka, Bangladesh
}

*Corresponding author: Dr. Md. Sazedul Karim Sarker, Senior Scientific Officer, Poultry Production Research Division, Bangladesh Livestock Research Institute, Savar, Dhaka 1341, Bangladesh. E-mail: sazdulkarim@yahoo.com

Received: 07 June 2017/Accepted: 19 June 2017/ Published: 29 June 2017

\begin{abstract}
A study was conducted to investigate the effect of dietary moringa leaf meal (MLM) as a natural alternative to antibiotic on the growth performance, meat quality and carcass yield of broiler chicken. A total of 270 day-old broiler chicks were randomly weighed and assigned to six dietary treatments having 45 birds in each. Each dietary treatment had three replicates of 15 birds and was reared in floor pens. Chicks were distributed in 4 different inclusion levels of MLM in diets; 0.5\%, 1.0\%, 1.5\% and 2.0\% with 2 control diets negative and positive. The birds were fed the experimental diets and water was provided without restriction throughout the experimental period. The results showed that significant $(\mathrm{P}<0.05)$ effect on final body weight and weight gain in dietary supplementation of $1.5 \%$ MLM as compared to that of control group. Better feed conversion (1.53) was observed at 1.5\% MLM group. Different levels of MLM exhibit significant influence on meat yield performance of broilers. There was no significant difference $(\mathrm{P}>0.05)$ observed among the average live weight, thigh meat, wing meat, drumstick meat, gizzard and abdominal fat of broilers. Breast meat, heart, liver, large intestine and dressing percentage showed significant difference. Lower mortality was found on diet supplemented with MLM. It is concluded that 1.5\% MLM in broiler diets can be used as natural feed additive for enhancing growth performance, organ development, meat yield and serum cholesterol of broilers as well as replacing of oxytetracycline.
\end{abstract}

Keywords: moringa leaf meal; antibiotic; growth performance; feed conversion ratio; dressing yield

\section{Introduction}

Moringa oleifera ( $M$. oleifera) belongs to the single genus monogeneric family Moringaceae and is well distributed in Africa and Asia. Apart from being a good source of vitamins and amino acids, it has medicinal uses. Moringa oleifera is a highly valued plant, distributed in many countries of the tropics and subtropics, where its various parts have been utilized historically as food and medicine. Many researchers (Sarker et al., 2009a,b; Griggs and Jacob, 2005; Peeters et al., 2006; Zhang et al., 2005; Anjum et al., 2005) suggested that natural herbal feed additives (plants/probiotic/prebiotic/organic acid etc.) can be used instead of antibiotic growth promoter in broiler production. Phytochemicals refer to only those chemicals which may have an impact on health, or on flavor, texture, smell, or color of the plants, but are not required by humans as essential nutrients. The leaves are considered to offer great potential for those who are nutritionally at risk and may be regarded as a protein and calcium supplement. Moringa leaves meal in the diets of adult indigenous chickens can be used up to $24 \%$ in partial substitution of groundnut cake meal, did not caused any adverse effect on 
nutrients retention and had significantly improved apparent coefficients of crude protein, energy and minerals utilization (Ossebi, 2010). A total of 250,000 species of flowering plants are referred to as medicinal plants. The World Health Organization (WHO) enlisted some 21,000 medicinal plant species containing different phytochemicals (Yadav et al., 2014; Penso, 1980). The annual growth of herbal market is about 15 percent and the global herbal market by 2050 is expected to be about US\$ 5 trillion (Purohit and Vyas, 2004; WHO, 2002). In Bangladesh, we have about 500 plant species as medicinal plant because of their therapeutic properties (Ghani, 2000). It is revealed that growth performance and meat quality can be enhanced by using medicinal plants and probiotics (Sarker et al., 2010a,b and 2011; Kim et al., 2002). According to Opara, 1996, leaf meal does not only serve as protein sources but also provide some necessary vitamins, minerals and also oxycarotenoids which causes yellow colour of broiler skin, shank and egg yolk. Gadzirayi et al. (2012) reported that the highest feed intake was recorded in birds offered 25\% Moringa oleifera leaf meal (MOLM) diet. They also reported that MOLM can be supplemented to soya bean meal at $25 \%$ inclusion level in broiler chickens. Our intension is to use moringa leaf meal in the broiler diet as feed additives (required up to $2 \%$ ) but not as feed supplement (can be used up to 30\%) because it is yet to be cultivated as fodder crop in Bangladesh.

Hence, the present study was conducted to investigate the effect of moringa leaf meal (MLM) as an alternative to antibiotic as natural feed additives on the growth performance, meat quality and carcass yield of broilers chicken.

\section{Materials and Methods}

This study was conducted at the broiler experimental shed, Poultry Production Research Division of Bangladesh Livestock Research Institute Savar, Dhaka. Straight run day old as hatched Cobb 500 broilers chicks were used for a period of 35 days to find out the effect of dietary level of moringa leaf meal (MLM) on feed consumption, weight gain, FCR, mortality of broilers. A total of 270 day-old broiler chicks were randomly weighed and assigned to six dietary treatments in a group of 45 birds each according to following CRD. Each dietary treatment had 45 birds with three replicates of 15 birds. Broilers were assigned to different inclusion levels of MLM diets; $0.5 \%, 1.0 \%, 1.5 \%$ and $2.0 \%$ with the basal diet. In the positive control (antibiotic group) $0.05 \%$ Oxytetracycline (OTC) was added in the basal diet whereas in negative control group no additives were added. The birds were fed the experimental diets as per BSTI standard namely starter (0-21 days) and finisher (22-35 days). Water was provided without restriction throughout the experimental period to the broilers.

\section{Results and Discussion}

The results in Table 1, shows that significant $(\mathrm{P}<0.05)$ effect on final body weight and weight gain in dietary supplementation of $1.5 \%$ MLM as compared to that of control as well as other MLM supplementary groups. Significantly lowest feed conversion ratio was (1.53) observed at 1.5\% MLM fed dietary group. Our result in feed conversion ratio of the birds fed moringa leaf meal based diets showed similarity with the result of El Tazi (2010). This might me the birds fed moringa based diets adequately utilized the nutrients they consumed. The results also coincided with the finding of Ebenebe et al. (2012) who reported chicks fed moringa based diets performed significantly $(\mathrm{P}<0.05)$ better than that of control group in term of higher weight gain and better feed conversion ratio. This improvement in body weight gain and feed conversion ratio may be attributed to rich content of nutrients in moringa (Sarwatt et al., 2004; Kakengi et al., 2003).

Different levels of MLM exhibit significant influence on dressing percentage and breast meat of broilers (Table 2 and Figure 1). There were no significant differences $(\mathrm{P}>0.05)$ observed in the live weight, drumstick meat, thigh meat, wing meat and dressing yield of broilers among the dietary feed additive groups (Table 2). Ologhobo et al. (2014) who mentioned that, higher mean values of slaughter weights were recorded for birds fed diets containing Moringa oleifera leaf meat as compared to those fed on the control diet.

In Table 3, heart, liver, large intestine and neck weight showed significant differences $(\mathrm{P}<0.05)$ among the treatments. No significant differences were observed in crop, gizzard, small intestine and abdominal fat among the groups. Although we didn't found significant difference in abdominal fat except a reducing trend compared to controls but significant reduction of abdominal fat with the increment of moringa leaf meal addition was revealed by Aderinola et al., (2013).

Blood lipid profile has an important role in the performance and carcass quality of broilers. Physiological studies have been adapted to correlate some of the blood parameters with the degree of fatness in broiler chickens. In this regard, it can be indicated that plasma very low density lipoprotein (VLDL) is a useful parameter to infer the degree of fatness in chickens. It is reported from the Table 4 that decreasing plasma (VLDL) level in broiler chicken by addition of MLM in the diet, which indirectly revealed about the hypo 
cholesterolemic effect of moringa. Similar statement was also made by Olugbemi et al., (2010) they stated the reason could probably be attributed to the hypocholesterolemic property of the moringa leaf meal.

Table 1. Effects of moringa leaf meal as feed additive on growth of broiler at $5^{\text {th }}$ weeks of age.

\begin{tabular}{|c|c|c|c|c|c|c|c|}
\hline \multirow{2}{*}{$\begin{array}{l}\text { Treat } \\
\text { ment }\end{array}$} & \multirow[t]{2}{*}{ Control } & \multirow{2}{*}{$\begin{array}{l}\text { Antibiotic } \\
(0.05 \% \text { OTC) }\end{array}$} & \multicolumn{4}{|c|}{ MLM (Moringa Leaf Meal) } & \multirow[t]{2}{*}{$\mathbf{L S}$} \\
\hline & & & $0.5 \%$ & $1.0 \%$ & $1.5 \%$ & $2.0 \%$ & \\
\hline $\mathrm{IBW}(\mathrm{g})$ & $42.58^{\mathrm{ab}} \pm 0.15$ & $42.66^{\mathrm{ab}} \pm 0.10$ & $42.44^{\mathrm{ab}} \pm 0.15$ & $42.93^{\mathrm{a}} \pm 0.13$ & $42.37^{b} \pm 0.18$ & $42.88^{\mathrm{a}} \pm 0.15$ & $*$ \\
\hline $\mathrm{FW}(\mathrm{g})$ & $2162.05^{\mathrm{b}} \pm 43$ & $2139.57^{\mathrm{b}} \pm 12$ & $2091.29^{\mathrm{b}} \pm 24$ & $2074.46^{\mathrm{b}} \pm 20$ & $2357.48^{\mathrm{a}} \pm 72$ & $2118.82^{\mathrm{b}} \pm 40$ & * \\
\hline WG $(g)$ & $2119.47^{\mathrm{b}} \pm 43$ & $2096.91^{\mathrm{b}} \pm 12$ & $2048.84^{\mathrm{b}} \pm 24$ & $2074.46^{\mathrm{b}} \pm 20$ & $2315.10^{\mathrm{a}} \pm 72$ & $2075.94^{\mathrm{b}} \pm 40$ & $*$ \\
\hline $\mathrm{FI}(\mathrm{g})$ & $3529.80 \pm 49$ & $3437.60 \pm 12$ & $3389.35 \pm 4$ & $3380.43 \pm 27$ & $3524.66 \pm 58$ & $3460.53 \pm 75$ & NS \\
\hline FCR & $1.66^{\mathrm{a}} \pm 0.01$ & $1.64^{\mathrm{a}} \pm 0.00$ & $1.65^{\mathrm{a}} \pm 0.01$ & $1.62^{\mathrm{a}} \pm 0.01$ & $1.53^{\mathrm{b}} \pm 0.07$ & $1.66^{\mathrm{a}} \pm 0.01$ & $*$ \\
\hline
\end{tabular}

IBW = Initial body weight, FW = Final weight, $\mathrm{WG}=$ Weight gain, FI = Feed intake, OTC - Oxytetracycline

${ }^{\mathrm{abc}}$ means having different superscripts in the same row differ significantly, *: P<0.05, NS: P> 0.05

Table 2. Effects of moringa leaf meal as feed additive on meat yield traits of broiler at $5^{\text {th }}$ weeks of age.

\begin{tabular}{|c|c|c|c|c|c|c|c|}
\hline & \multirow[t]{2}{*}{ Control } & \multirow{2}{*}{$\begin{array}{c}\text { Antibiotic } \\
(0.05 \% \text { OTC })\end{array}$} & \multicolumn{4}{|c|}{ (\% of MLM Diet) } & \multirow[t]{2}{*}{$\mathbf{L S}$} \\
\hline & & & 0.5 & 1.0 & 1.5 & 2.0 & \\
\hline Live wt. (g/bird) & $2012 \pm 70$ & $1944.67 \pm 73$ & $2006.67 \pm 41$ & $2054.67 \pm 40$ & $2039 \pm 26$ & $2017.33 \pm 21$ & NS \\
\hline Drumstick meat (g) & $159 \pm 7$ & $155.33 \pm 5$ & $161 \pm 5$ & $168.33 \pm 9$ & $163.66 \pm 9$ & $166.66 \pm 3$ & NS \\
\hline Thigh meat $(\mathrm{g})$ & $198.33 \pm 8$ & $191.33 \pm 6$ & $191.33 \pm 12$ & $212.66 \pm 12$ & $191.66 \pm 10$ & $212.33 \pm 5$ & NS \\
\hline Breast meat $(\mathrm{g})$ & $479.6^{\mathrm{b}} \pm 12$ & $476.33^{b} \pm 30$ & $522^{\mathrm{ab}} \pm 31$ & $559.33^{\mathrm{a}} \pm 14$ & $509.33^{\mathrm{ab}} \pm 8$ & $528^{\mathrm{ab}} \pm 11$ & $*$ \\
\hline Wing meat $(\mathrm{g})$ & $146 \pm 14.42$ & $136.66 \pm 9.83$ & $146.33 \pm 17.45$ & $150 \pm 6.65$ & $151.33 \pm 4.91$ & $121 \pm 3.05$ & NS \\
\hline Dressing yield & $1309.33 \pm 36$ & $1306.33 \pm 72$ & $1363.33 \pm 40$ & $1428 \pm 35$ & $1367.67 \pm 42$ & $1348.33 \pm 16$ & NS \\
\hline Dressing $(\%)$ & $70.67^{\mathrm{b}} \pm 1.52$ & $73.2^{\mathrm{ab}} \pm 0.92$ & $76.75^{\mathrm{a}} \pm 3.12$ & $74.75^{\mathrm{ab}} \pm 0.25$ & $73.74^{\mathrm{ab}} \pm 0.98$ & $73.01^{\mathrm{ab}} \pm 0.27$ & $*$ \\
\hline
\end{tabular}

${ }^{\mathrm{ab}}$ means having different superscripts in the same row differ significantly, $*$ : $\mathrm{P}<0.05$;

NS: P> 0.05

Table 3. Effects of moringa leaf meal (MLM) on development of intestinal organs in broiler chickens.

\begin{tabular}{|c|c|c|c|c|c|c|c|}
\hline \multirow{2}{*}{ Organ wt (g) } & \multirow{2}{*}{ Control } & \multirow{2}{*}{ Antibiotic } & \multicolumn{4}{|c|}{ MLM } & \multirow[t]{2}{*}{ Level of Sig } \\
\hline & & & $0.5 \%$ & $1.0 \%$ & $1.5 \%$ & $2.0 \%$ & \\
\hline Crop wt. & 17.66 & 13.33 & 13.00 & 16.00 & 18.00 & 9.00 & NS \\
\hline Heart wt. & $12.00^{\mathrm{a}}$ & $9.66^{\mathrm{b}}$ & $9.00^{\mathrm{b}}$ & $9.33^{\mathrm{b}}$ & $9.00^{\mathrm{b}}$ & $11.66^{\mathrm{a}}$ & $*$ \\
\hline Liver wt. & $51.66^{\mathrm{a}}$ & $41.00^{\mathrm{ab}}$ & $42.33^{\mathrm{ab}}$ & $40.00^{\mathrm{ab}}$ & $41.66^{\mathrm{ab}}$ & $39.00^{\mathrm{b}}$ & $*$ \\
\hline Gizzard wt. & 31.66 & 32.00 & 33.33 & 29.00 & 32.00 & 26.66 & NS \\
\hline Small Intes. wt. & 58.33 & 53.66 & 56.66 & 41.33 & 52.00 & 43.66 & NS \\
\hline Large Intes. wt. & $19.00^{\mathrm{a}}$ & $12.33^{\mathrm{b}}$ & $16.66^{\mathrm{ab}}$ & $15.66^{\mathrm{ab}}$ & $16.66^{\mathrm{ab}}$ & $13.00^{\mathrm{ab}}$ & $*$ \\
\hline Abdom fat wt. & 25.00 & 25.33 & 18.00 & 17.66 & 22.00 & 16.33 & NS \\
\hline Neck weight & $48.00^{\mathrm{b}}$ & $54.33^{\mathrm{ab}}$ & $56.00^{\mathrm{ab}}$ & $61.33^{\mathrm{a}}$ & $57.33^{\mathrm{ab}}$ & $53.33^{\mathrm{ab}}$ & $*$ \\
\hline
\end{tabular}

${ }^{\mathrm{ab}}$ means having different superscripts in the same row differ significantly, $*$ : $\mathrm{p}<0.05$. NS: $\mathrm{P}>0.05$

Table 4. Effects of moringa leaf meal as natural feed additive on serum lipid profile level of broiler at $5^{\text {th }}$ weeks of age.

\begin{tabular}{|c|c|c|c|c|c|c|c|}
\hline \multirow[t]{2}{*}{ Parameter } & \multirow[t]{2}{*}{ Control } & \multirow{2}{*}{$\begin{array}{l}\text { Antibiotic } \\
(0.05 \% \\
\text { OTC) }\end{array}$} & \multicolumn{4}{|c|}{ MLM (Moringa Leaf Meal) } & \multirow{2}{*}{$\begin{array}{l}\text { Level } \\
\text { of Sig. }\end{array}$} \\
\hline & & & $0.5 \%$ & $1.0 \%$ & $1.5 \%$ & $2.0 \%$ & \\
\hline $\begin{array}{l}\text { Total } \\
\text { Cholesterol } \\
(\mathrm{mg} / \mathrm{dl})\end{array}$ & $143.33 \pm 9.06$ & $131.33 \pm 5.89$ & $130.00 \pm 5.19$ & $127.33 \pm 6.56$ & $138.00 \pm 6.55$ & $133.33 \pm 3.28$ & NS \\
\hline HDL (mg/dl) & $41.66 \pm 2.18$ & $41.00 \pm 1.00$ & $42.33 \pm 2.02$ & $43.33 \pm 2.96$ & $42.66 \pm 1.20$ & $40.33 \pm 2.72$ & NS \\
\hline LDL (mg/dl) & $73.66 \pm 31.97$ & $82.33 \pm 3.84$ & $91.33 \pm 3.84$ & $87.66 \pm 3.38$ & $88.66 \pm 3.52$ & $71.00 \pm 1.15$ & NS \\
\hline $\operatorname{VLDL}(\mathrm{mg} / \mathrm{dl})$ & $31.86 \pm 3.42^{\mathrm{a}}$ & $22.93 \pm 1.87^{\mathrm{bc}}$ & $29.06 \pm 1.21^{\mathrm{ab}}$ & $25.53 \pm 2.49^{\mathrm{abc}}$ & $25.60 \pm 0.90^{\mathrm{abc}}$ & $19.20 \pm 2.53^{c}$ & $*$ \\
\hline $\mathrm{TG}(\mathrm{mg} / \mathrm{dl})$ & $159.33 \pm 17.13^{\mathrm{a}}$ & $114.66 \pm 9.38^{\mathrm{bc}}$ & $145.33 \pm 6.06^{\mathrm{ab}}$ & $127.66 \pm 12.46^{\mathrm{abc}}$ & $128.00 \pm 4.50^{\mathrm{abc}}$ & $96.00 \pm 12.66^{\mathrm{c}}$ & * \\
\hline
\end{tabular}

HDL - High density lipoprotein, LDL- Low density lipoprotein, VLDL- Very low density lipoprotein, TG- Tri glyceride a,b,c, Mean with different superscripts are significantly different; *, P<0.05; NS: $\mathrm{P}>0.05$ 


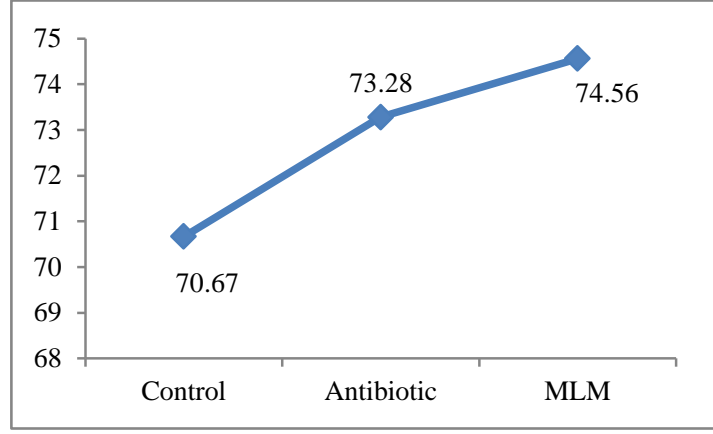

Dressing yield $(\%)$

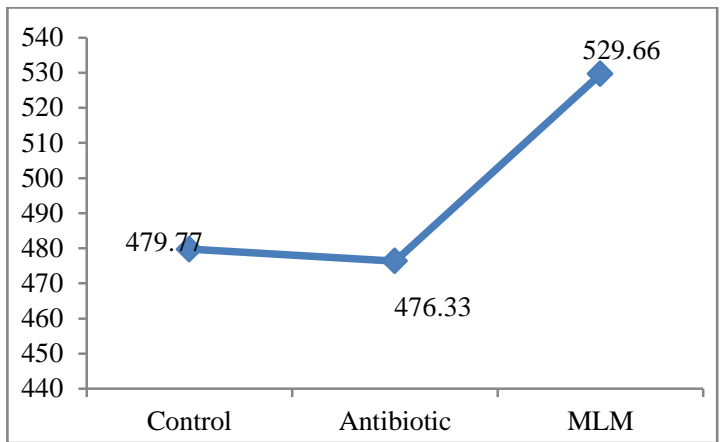

Breast meat $(\mathrm{g})$

Figure 1. Trend of dressing yield percent and breast meat of broilers in control, antibiotic and MLM added groups.

\section{Conclusions}

Improvement of weight gain and feed conversion ratio was observed in 1.5\% MLM supplemented group compared to other groups including antibiotic fed birds. Addition of moringa leaf meal didn't affect $(\geq 0.05)$ on internal organ development rather improved dressing and dressing yield. Considering the findings it can be concluded that $1.5 \%$ moringa leaf meal is replaceable in place of antibiotic in terms of growth performance, internal organ development and meat yield traits.

\section{Conflict of interest}

None to declare.

\section{References}

Aderinola OA1, TA1 Rafiu, AO Akinwumi, TA Alabi and OA Adeagbo, 2013. Utilization of Moringa oleifera leaf as feed supplement in broiler diet. Int. J. Food, Agri. Vet. Sci., 3: 94-102.

Anjum, MI, AG Khan, A Azim and M Afzal, 2005. Effect of dietary supplementation of multi-strain probiotic on broiler growth performance. Pakistan Vet. J., 25: 237-241.

Ebenebe CI, CO Umegechi, Aniebo and BO Nweze, 2012. Comparison of haematological parameters and weight changes of broiler chicks fed different levels of Moringa oleifera diet. Inter. J. Agric. Bio Sci., 1: 2325.

El Tazi, 2010. Effect of feeding different levels of Moringa oleifera leaf meal on the performance and carcass quality of broiler chicks. Int. J. Sci. Res. (IJSR), 2319-7064.

Gadzirayi CT, B Masamha, JF Mupangwa and SW Bindura, 2012. Performance of broiler chickens fed on mature Moringa oleifera leaf meal as a protein supplement to Soyabean Meal. Int. J. Poult. Sci., 11: 5-10.

Ghani A, 2000. Vheshaja Oshudh (Herbal Medicine), Bangla Academy Dhaka, Bangladesh.

Griggs, JP, and JP Jacob, 2005. Alternatives to antibiotics in organic poultry production. J. Appl. Poult. Res., 14: $750-756$.

Grundy S M, 1990. Cholesterol and coronary disease: future directions. J. American Med., 265: 3053-3059.

Kakengi AMV, MN Shem, SV Sarwatt and T Fujihara, 2003. Can Moringa oleifera be used as a protein supplement to ruminants? Asian- Aust. J. Anim. Sci., 18: 42-47.

Kim HS, DJ Yu, SY Park, SJ Lee, CH Choi, CK Seong and KS Ryu. 2002. Effects of single or mixed feeding of Lactobacillus and yeast on performance, nutrient digestibility, intestinal microflora, and fecal $\mathrm{NH}_{3}$ gas emission in laying hens. Korean J. Poult. Sci., 29: 225-231.

Ologhobo AD, EI Akangbe, IO Adejumo and O Adeleye, 2014. Effect of Moringa oleifera leaf meal as replacement for oxytetracycline on carcass characteristics of the diets of broiler chickens. Annual Res. Rev. Biol., 4: 423-431.

lugbemi TS, SK Mutayoba and FP Lekule, 2010. Effect of Moringa (Moringa oleifera) inclusion in cassava based diets fed to broiler chickens. Int. J. Poult. Sci., 9: 363- 367.

Opara CC, 1996. Studies on the use of Alchornia ordifolia leaf meal as feed ingredient in poultry diets. M.Sc Thesis, Federal University of Technology, Owerri, Nigeria, pp. 150-159.

Ossebi W, 2010. Etudes digestive, métabolique nutritionnelle des farines de feuilles de légumineuses incorporées dans des ration salimentaires chez les poulets locaux du Sénégal casdes feuilles de Moringa oleifera (Lam.), de Leucaena leucocephala (Lam.) et de Cassia tora (Linn.). Thèse Méd. Vét., EISMV: Dakar, pp. 26. 
Peeters E, B Driessen, and R Geers. 2006. Influence of supplemental magnesium, tryptophan, vitamin C, vitamin E, and herbs on stress responses and pork quality. J. Anim. Sci., 84: 1827-1838.

Penso G, 1980. WHO inventory of medicinal plant s used in different countries. - Geneva, Switzerland.

Purohit SS and SP Vyas, 2004. Marketing of medicinal and aromatic plants in Rajasthan, National Consultative Workshop on Medicinal and Artomatic Plants, held at GBPUAT, Pantnagar.

Rajangam J, RS Azahakia Manavalan, T Thangaraj, A Vijayakumar and N Muthukrishan, 2001. Status of production and utilisation of Moringa in Southern India. In: Lowell, J.F. (Ed.), The Miracle Tree/ The Multiple Attributes of Moringa. CTA. USA.

Sarker MSK, SY Ko, GM Kim and CJ Yang, 2009a. Effect of green tea and green tea probiotics on meat quality in broilers. Sixth Int'l. Poult. Show and Seminar, WPSA-BB, 5-7 March, Dhaka, Bangladesh.

Sarker MSK, DH Jang, GM Kim and CJ Yang, 2009b. Bamboo vinegar liquid probiotics for replacing antibiotic in broilers. $17^{\text {th }}$ European Symposium on Poultry Nutrition, Heriot-Watt University, Edinburgh, Scotland, UK.

Sarker MSK, GM Kim and CJ Yang. 2010a. Effect of green tea and biotite on performance, meat quality and organ development in Ross broiler. Egypt. Poult. Sci., 30: 77-88.

Sarker MSK, SR Park, GM Kim, and CJ Yang, 2010b. Hamcho (Salicornia herbacea) with probiotics as alternative to antibiotic for broiler Production. J. Med. Plants Res., 4: 415-420.

Sarker MSK, GM Kim, ME Hossain, MF Sharmin, KS Huque and CJ Yang, 2011. Effect of Mixed Probiotics Treated with Alisma canaliculatum, Laminaria japonica and Cornus officinalis on Oxidation, Cholesterol and Fatty Acids Profile in Broiler Meat. $9^{\text {th }}$ Asia Pacific Poultry Conference. Taipei International Convention Center, Taipei, Taiwan. 20-23 March.

Sarwatt, SV, MS Milangha, FP Lekule, and N Madalla, 2004. Moringa oleifera and cottonseed cake as supplements for small holder dairy cow fed napier grass. Livestock Res. Rural Dev., 16: 38-44.

World Health Organization (WHO). 2002. Traditional Medicine Strategy 2002-2005. Website: www.who.int/medicines/library/trm/trm_start_eng.pdf.

Yadav KN, PV Kadam, JA Patel and MJ Patil, 2014. Strychnos potatorum: Phytochemical and pharmacological review. Pharmacogn Rev., 8: 61-66.

Zhang A, B Lee, S Lee, K Lee, G An, K Song and C Lee, 2005. Effect of yeast (Saccharomyces cervisiae) cell components on growth performance, meat quality, and lleal mucosa development of broiler chicks. Poult. Sci., 84: 1015-1021. 